\title{
Body Donation Program for Anatomical Teaching: The Perception of Brazilian Students
}

\section{da Costa Sobrinho OP1, de Lucena JD2, Oliveira da Silva $\mathrm{FR}^{2}$, Brasileiro Leal KM1ㅜ, Ferreira a Maciel Gusmão JN², Pinheiro Gusmão $\mathrm{CT}^{5}$, Maiely Lima $\mathrm{S}^{3}$, Lima Barbosa $\mathrm{ML}^{4}$, Gustavo Scafuri $\mathrm{A}^{2,3}$, Binda} Pimenta $\mathrm{H}^{4}$ and Santos Cerqueira G2*

\section{Research Article}

Volume 2 Issue 2

Received Date: April 20, 2018

Published Date: May 31, 2018

${ }^{1}$ League of Anatomy and Surgery, Federal University of Ceara, Brazil

${ }^{2}$ Faculty of Medicine, Post-Graduate Program in Morphofunctional Sciences, Federal University of Ceara, Brazil

${ }^{3}$ Federal University of Piaui, CMRV, Brazil

${ }^{4}$ Postgraduate Program in Biomedical Sciences, Federal University of Piaui, Brazil

5Postgraduate Program Unichristus, Brazil

*Corresponding author: Dr. Gilberto Santos Cerqueira, Department of Morphology - Federal University of Ceara, Street Delmiro de Farias s/n - Campus Porangabussu - Ceara, CEP: 64.204-035, Brazil, Tel: +55 (85) 3366-8485; Email: giufarmacia@hotmail.com

\section{Abstract}

The donation of bodies is constituted as an alternative to the teaching learning of human anatomy, since the dissection of materials from these works as a foundation for excellence education among health professionals. Due to the relevance of the topic addressed, the objective of the study was to evaluate the factors that influence the positioning of people, as well as the knowledge of the same in relation to this subject. In this way, a qualitative field research was carried out through the application of semi-structured questionnaires to 36 students of the Biology, Nutrition and Nursing course. The results of these were interpreted and exposed through statistical data. It was evidenced that $83.3 \%$ of the interviewees would not donate the body for teaching and research in Universities, among which, the majority (53.2\%) claimed the desire to be buried or cremated, while the minority $(9.1 \% \%)$ claimed to be ashamed to be recognized. Among those who voted in favor $(16.7 \%)$, there was a balance between the options that suggested the costs to the family and the claim to help society and science. As for the knowledge about the subject, $97.2 \%$ claimed to have only one prior notion and $2.8 \%$ did not know it. Given this, it is perceived that the donation of bodies is a very controversial topic, either because it involves religions and traditions, or because it is little debated by society. The need for awareness campaigns about the importance of the theme in question, as well as the lack of taboos that exists on the theme, are then discussed. 
Keywords: Anatomy; Cadaver Donation of Bodies; Teaching Medical education; Medicine Medical Teacher

\section{Introduction}

The use of human cadavers began systematically in the late Middle Ages and this use has been evolving over the years $[1,2]$. Thus, it is highlighted that the greatest source of these is through the donation of bodies, characterized as important didactic material and research for the medical and biological sciences courses [3]. The use of human cadavers for medical teaching purposes is a common practice throughout the world and throughout history. This use, however, is not devoid of ethical and social dilemmas [4]. From a bioethical point of view, the human corpse should not be seen as a simple object of study, since an emotional and affective bond surrounds it with the individuals with whom it has established a relationship, and this emotional bond is an important hindrance to the donation for the study anatomical [5]. The use of cadavers by the professional has an aspect not only of technical learning, but also as a way of perceiving and reflecting on human limitations and dealing with death as an occurrence of life, which is essential for those who work in the area of health [6]. In recent years several universities in the world have faced difficulty in acquiring new cadavers for teaching and researching anatomy.

In this context, it is worth mentioning that the donation of bodies is of fundamental importance for the study of anatomy, defined as a basic discipline for the training of health professionals. It is possible to know the morphology and the location of organs / structures of the human body and its different functions [7]. Human bodies are essential for teaching and research in health. In order to have a full training of the professionals who work in it, it is necessary during their formation that they have the opportunity to study the anatomy directly in human bodies, in not only artificial forms and books. The contact with the corpse is fundamental, besides its contribution to the deepening of the anatomical learning, in the humanistic formation of the students and their perception about the limitations and the confrontation of the death [8]. In Brazil, the bodies used for dissection in educational institutions are mostly unclaimed bodies obtained through a complex bureaucratic process that ends up restricting significantly the number of cadavers available for study. Other bodies become available by donation, but still in very small numbers, since this is a theme little known by the general population. We are experiencing a critical moment, without a concrete source of obtaining human material, consequently running the risk of training professionals who cannot have this resource to adequately carry out this fundamental stage of their training [9]. Thus, based on this premises the objective of the study was to evaluate the positioning of biological and health sciences students on the donation of bodies for the teaching and research of anatomy.

\section{Methodology}

A descriptive, cross-sectional exploratory study with a quantitative approach was carried out with 105 students of Biology, Nutrition and Nursing from a Federal University of the Northeast of Brazil. The sample was of the convenient type. For the selection of the individuals who participated in the sample, we used the snowball method recommended by researcher, following the following criteria of inclusion, have active enrollment in the university and be over 18 years old [10]. The sole exclusion criterion was refusal to participate after being informed of the study's designated objectives. The instrument used for data collection was a semi-structured questionnaire, containing easyto-understand questions and previously tested in a pilot study. This instrument was a questionnaire based on the model of Freitas, et al. adapted through self-fulfillment and in a secretive way [11]. Data collection was performed by a researcher and two previously trained students to apply the questionnaire. The data analysis was used descriptive statistics. The Excel 2003 computer program was used to organize the database and the GraphPad Prism version 5.0 applications was used as statistical instrument. Senso considered significant values that presented the $\mathrm{p}<0.05$. This study followed the rigor of research ethics. This research has no conflict of interest and follows the precepts of Resolution 466/12 of the National Health Council, which regulates research involving human beings and Declaration of Helsinki [12]. All participants signed a free and informed consent form. In this study there is no conflict of interest.

\section{Results}

All students reported using pieces of human cadavers to study in their practical classes at the university. Of those, only $16.7 \%$ said they would donate their body to the teaching and research of anatomy, while $63.3 \%$ said they would not donate (Figure 1). 


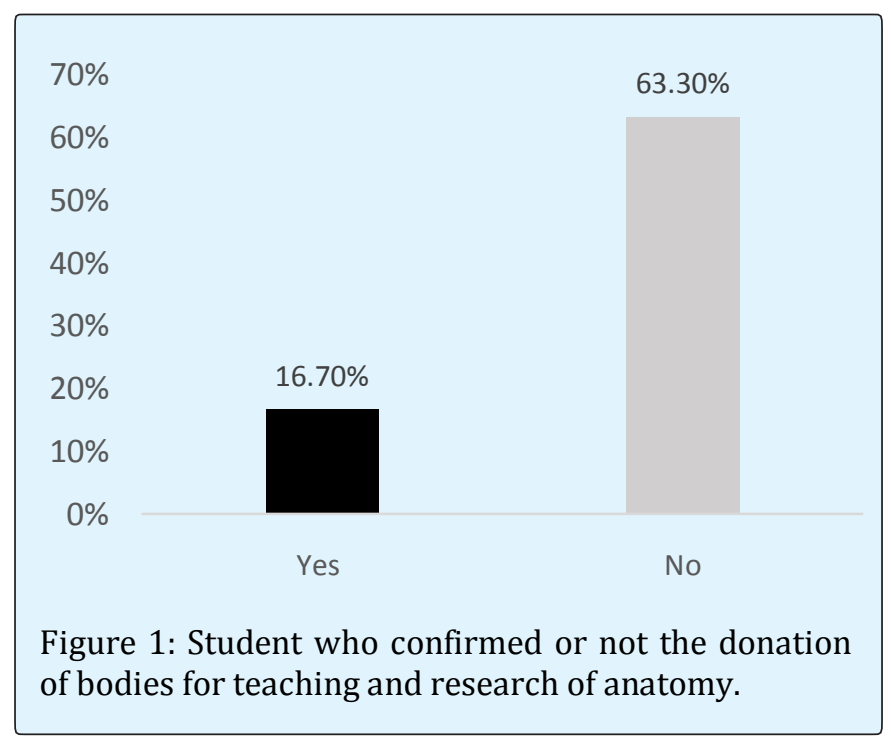

Among those who said they would donate their body for teaching and researching anatomy, when asked about the reasons $83.3 \%$ said they would like to contribute science to improving teaching and medical treatments. Already $16.7 \%$ stated that they would not like to generate funeral costs for the family. Since in Brazil these services are very expensive (Figure2).

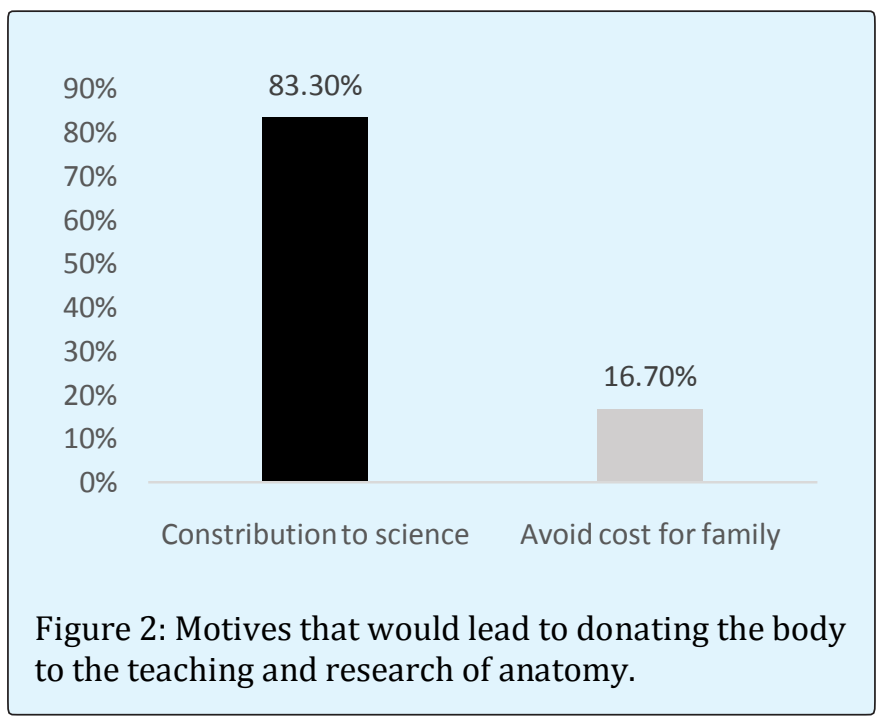

Among the several factors that led the interviewees to affirm that they would not donate the body to anatomy teaching, $56.7 \%$ had the desire to be buried or cremated. Already $17.04 \%$ stated that they would be ashamed to be recognized in the anatomy laboratory, $13.13 \%$ stated that religion or family did not allow the donation of the body.

\begin{tabular}{|c|c|}
\hline Reason & $\mathbf{\%}$ \\
\hline Desire to be buried or cremated & 56,70 \\
\hline Shame to be recognized & 17,04 \\
\hline Religious motivation & 13,13 \\
\hline Family does not accept & 13,13 \\
\hline
\end{tabular}

Table 1. Reason for non-donation of bodies for anatomy teaching and research.

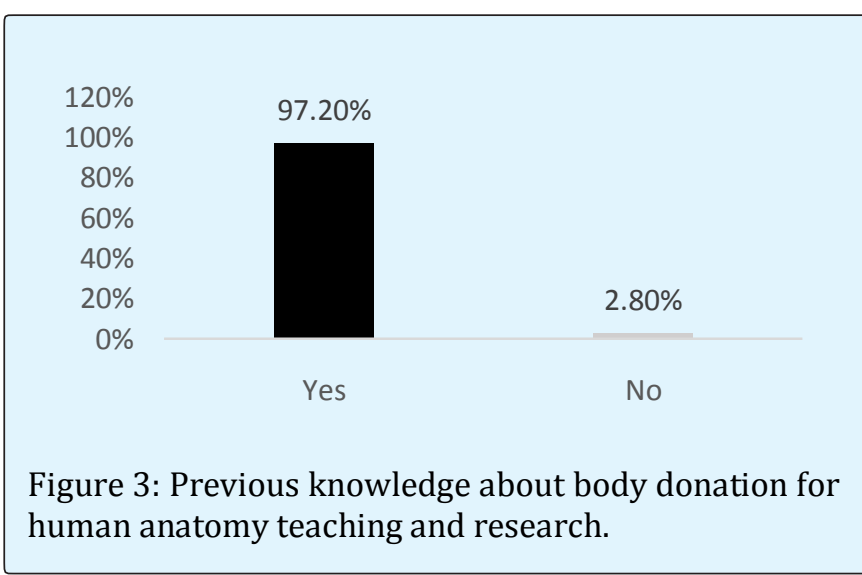

It was observed that $97.2 \%$ of the interviewees showed previous knowledge about the body donation program for anatomy teaching and research, and only $2.8 \%$ did not know this type of program.

\section{Discussion}

The use of cadavers in teaching and research presents strong axiological ambiguity within our society. By the customs and customs, we always use, almost exclusively, the unclaimed corpse as a source for teaching and research. This, however, has never been, let us say, sufficient, since necessity, not infrequently, is greater than availability. Both the literature and the history of mankind provide us with numerous examples of cases involving theft, trade, or murder of bodies for educational institutions. The use of human cadavers, even if only for the demonstration of anatomical structures, was considered indispensable to the teaching-learning process in the study of human anatomy. The student's handling of the cadaver was seen as a way to strengthen the humanization of future health professionals, reflecting on their behaviors with patients [5]. The use of human material in anatomy education depends on the generosity of the body's donors. However, in the last decades, the global awareness of the legitimacy of cadaver donation has intensified, considering today the form worthy of bridging this lack [13]. 
In this study we observed that few students would donate their bodies to the teaching and research of anatomy or a very low index of donation. Our data diverge with studies carried out among university students from the state of Ceará, Brazil, where the authors verified that $51(44 \%)$ would donate their bodies to universities [14]. In a survey carried out with secondary students, 128 (57\%) of the students were not in favor of donating their body to study. The largest organ donation program in Brazil at the Federal University of Health Sciences in Porto Alegre, the pioneer in Brazil, has since found that the donation program since its inception, found that 297 people registered as donors and 48 bodies were donated for the University, compared with 23 bodies received between 2001-2007. This increase in the number of bodies allowed the implementation of the Dissecting Workshop, in which students prepare high quality anatomical specimens to be exhibited at the Museum of Anatomy [15].

It was also verified that of the reasons that would prevent the donation of bodies the students reported the disrespect on the part of the students. Thus, even in the medical school, few students know the law and the acceptance of donation of their bodies is small, given the disrespect on the part of colleagues. Thus, there is a need to deal more with legislation and ethics during anatomy classes, so that disrespect for the corpse is not an obstacle to donation, as well as ignorance about legislation. A portion of the interviewees have already heard about the donation of cadavers to the anatomical study, however all were not aware of the current Brazilian legislation. While most interviewees are aware of the importance of cadaver donation for study, most interviewees report that they would not donate their own body for anatomical study, primarily because of factors such as disrespect, shame or religious beliefs, or the simple desire to be buried. These data corroborate with studies carried out in Ceará, Brazil [16]. It is alleged that anonymity aims not to expose the image of the donor and his family, but it is undeniable that this also has the desirable effect of omitting the social dimension of the corpse being a conflict in the process of donating bodies [17].

In a recent study, [18] researchers stated that in order to maintain donation programs, it is essential first to understand the meaning of public opinion and then adopt strategies to improve donations. In addition, the same author suggested that donor profile surveys provide useful information about donors and the reasons they donate, which can be used to direct potential donors when setting donor programs, to circumvent difficulties in finding donors, or to monitor changes in donor profiles $[18,19]$. Body donation research shows that the identification of donor profiles facilitated campaigns aimed at informing the target population about voluntary donation of cadavers [19].

It was verified the need to implement a popular education program on the importance of body donation for teaching and anatomical research among students and the population in general, since in the Brazilian northeast the population does not have the culture to donate the body for teaching and research. The lack of donation of bodies can contribute to an anatomically inadequate formation, since the synthetic parts do not allow the accuracy of the anatomical and topographic description and do not allow the manipulation of the structures. In addition, dissection is an important tool for anatomical study and training to perform surgery. Universities should contribute through extension by creating body donation programs for study and research as well as promoting educational campaigns to increase body donation and break down cultural roots

\section{References}

1. Ghosh Sk (2015) Human cadaveric dissection: a historical account from ancient Greece to the modern era. Anat Cell Bio 48(3): 153-169.

2. Rocha AO, Leonardo Thomaz, Pedron J, Simonetti Ll, Girotto, Marina C, et al. (2015) The Role of Body Donation Programs in Improving Anatomy Education. The Faseb Journal 29(1): 547.

3. Ajita R, Singh YI (2007) Body donation and its relevance in anatomy learning - a review. J Anat Soc India 56(1): 44-47.

4. Shaikh ST (2015) Cadaver dissection in anatomy: the ethical aspect. Anat Physiol1: S5-7.

5. Jones DG (1995) The Human Cadaver: An Assessment of the Value We Place on the Dead Body, Perspectives on Science and Christian Faith 47: 43-51.

6. Aziz MA, Mckenzie JC, Wilson JS, Cowie RJ, Ayeni SA, et al. (2002) The human cadaver in the age of biomedical informatics. Anat Rec 269(1): 20-32.

7. Morar S, Dumbrava Dp, Cristian A (2008) Ethical and legal aspects of the use of the dead human body for teaching and scientific purposes. Revista Romana de Bioetica 6(4). 


\section{Journal of Human Anatomy}

8. Hasan T (2011) Is dissection humane? Journal of Medical Ethics and History of Medicine 4: 4.

9. Joana ED, Marcus VA, Ana Paula CA, Rodrigo FZ, Edson GS, et al. (2011) The Dados preliminares de um modelo de programa de doação de corpos: Programa de Doação de Corpos da UFCSPA. Revista da AMRIGS, Porto Alegre 55(1): 7-10.

10. Biernarcki P, Waldorf D (1981) Snowball samplingproblems and techniques of chain referral sampling. Sociological Methods and Research 10(2): 141-163.

11. Freitas APF, Pinto RH, Lima TAJ, Vasconcelos TC, Cerqueira GS, et al. (2007) Occupational exposure of workers at gas stations in the backwoods Paraibano. In: XV Congresso Brasileiro de Toxicologia. Rev Bras de Toxicologia 20(1): 310-331.

12. Costa Lf, Feijos Ags (2009) Doação de corpos: estudo comparativo luso brasileiro sobre a utilização do corpo humano para ensino e pesquisa. X Salão de Iniciação Científica - PUCRS.

13. Brasil (2012) Ministério da Saúde. Conselho Nacional de Saúde. Resolução n. 466, de 12 de dezembro de 2012. Aprova diretrizes e normas regulamentadoras de pesquisas envolvendo seres humanos. Brasília, Diário Oficial da União, 12 dez.

14. João Gabriel Damasceno P, Francisco Afrânio PN, Lucas Bernardo M, Beatriz Soares B, Lucas Costa
Carvalho A, Scafuri AG (2014) Donations of cadavers for teaching in universities: evaluation of medical students from federal university of Ceará. Revista Saúde E Ciência Online 3(1).

15. Rocha AO, Pedron J, Simonetti L, Girotto Marina, Thomaz L, et al. (2015) The Role of Body Donation Programs in Improving Anatomy Education. The Faseb Journal 29(1): 547.

16. Francisco Afranio PN, Thaís Alexandrino O, Karen Lopes C, Lucas Bernardo M, Ariel Gustavo S, Helson Freitas de $S$ (2014) Evaluation of statement that carry no donation of corpse for teaching in universities by students from highschools in Fortaleza/ce. Revista Saúde e Ciência Online 3(1).

17. Kim JH (2012) Exposição de corpos humanos: o uso de cadáveres como entretenimento e mercadoria. Mana 18(2): 309-348.

18. Lopes ID, Teixeira BD, Cortez PO, da Silva GR, de Sousa Neto AI, et al. (2017) Use of human cadavers in teaching of human anatomy in brazilian medical faculties. Acta Scientiarum. Biological Sciences 39(1): 1.

19. da Rocha AO, De Campos D, Farina MA, Pacini GS, Girotto MC, et al. (2017) Using body donor demographics to assist the implementation of donation programs in Brazil. Anat Sci Educ 10(5): 475-486. 